\title{
HUBUNGAN ANTARA FUNGSI DAN BIDANG GARAPAN \\ MANAJEMEN SEKOLAH
}

Nama : Muhammad Ihsanudin

\section{Nim : 0142S1A018036}

\section{A. Fungsi Manajemen}

Dikemukakan bahwa manajemen pendidikan merupakan suatu kegiatan. Kegiatan yang dimaksud adalah tindakan-tindakan yang mengacu pada fungsi-fungsi manajemen.

Untuk memahami lebih jauh tentang manajemen pendidikan, dibawah ini akan mempaparkan tentang fungsi-fungsi manajemen pendidikan dalam perspektif persekolahan, dengan merujuk kepada pemikiran G.R. Terry, meliputi : (1) perencanaan (planning); (2) pengorganisasian (organizing); (3) pelaksanaan (actuating) dan (4) pengawasan (controling).

\section{Perencanaan (planning)}

Perencanaan (planning) adalah pemilihan dan penetapan tujuan organisasi dan penentuan strategi, kebijaksanaan, proyek, program, prosedur, metode, sistem, anggaran dan standar yang dibutuhkan untuk mencapai tujuan. Pembuatan keputusan banyak terlibat dalam fungsi ini.".

\section{Pengorganisasian (organizing)}

Fungsi manajemen berikutnya adalah pengorganisasian (organizing). George R. Terry (1986) mengemukakan bahwa : "Pengorganisasian adalah tindakan mengusahakan hubunganhubungan kelakuan yang efektif antara orang-orang, sehingga mereka dapat bekerja sama secara efisien, dan memperoleh kepuasan pribadi dalam melaksanakan tugas-tugas tertentu, dalam kondisi lingkungan tertentu guna mencapai tujuan atau sasaran tertentu".

\section{Pelaksanaan (actuating)}


Dari seluruh rangkaian proses manajemen, pelaksanaan (actuating) merupakan fungsi manajemen yang paling utama. Dalam fungsi perencanaan dan pengorganisasian lebih banyak berhubungan dengan aspek-aspek abstrak proses manajemen, sedangkan fungsi actuating justru lebih menekankan pada kegiatan yang berhubungan langsung dengan orang-orang dalam organisasi.

George R. Terry (1986) mengemukakan bahwa actuating merupakan usaha menggerakkan anggota-anggota kelompok sedemikian rupa hingga mereka berkeinginan dan berusaha untuk mencapai sasaran perusahaan dan sasaran anggota-anggota perusahaan tersebut oleh karena para anggota itu juga ingin mencapai sasaransasaran tersebut. Dari pengertian di atas, pelaksanaan (actuating) tidak lain merupakan upaya untuk menjadikan perencanaan menjadi kenyataan, dengan melalui berbagai pengarahan dan pemotivasian agar setiap karyawan dapat melaksanakan kegiatan secara optimal sesuai dengan peran, tugas dan tanggung jawabnya.

\section{Pengawasan (controling)}

Pengawasan (controlling) merupakan fungsi manajemen yang tidak kalah pentingnya dalam suatu organisasi. Semua fungsi terdahulu, tidak akan efektif tanpa disertai fungsi pengawasan.

Pengawasan manajemen adalah suatu usaha sistematik untuk menetapkan standar pelaksanaan dengan tujuan - tujuan perencanaan, merancang sistem informasi umpan balik, membandingkan kegiatan nyata dengan standar yang telah ditetapkan sebelumnya, menentukan dan mengukur penyimpangan-penyimpangan, serta mengambil tindakan koreksi yang diperlukan untuk menjamin bahwa semua sumber daya perusahaan dipergunakan dengan cara paling efektif dan efisien dalam pencapaian tujuan-tujuan perusahaan.

\section{B. Fungsi-Fungsi Esensial Sekolah}

1. penstrukturan waktu 
2. Penstrukturan aktivitas yang harus diikuti peserta didik

3. Pendefinisian kecerdasan, kemampuan intelektual, prestasi dan prilaku yang baik

4. Penilaian

5. Pemisahan peran dan tanggung jawab guru dan peserta didik

6. Supervisi dan pengawasan terhadap peserta didik

7. Pertanggung jawaban

(Sulfemi, (2019 : 4.).

\section{Bidang Kegiatan Pendidikan}

Berbicara tentang kegiatan pendidikan, di bawah ini beberapa pandangan dari para ahli tentang bidang-bidang kegiatan yang menjadi wilayah garapan manajemen pendidikan. Ngalim Purwanto (1986) mengelompokkannya ke dalam tiga bidang garapan yaitu :

1. Administrasi material, yaitu kegiatan yang menyangkut bidang-bidang materi/ benda-benda, seperti ketatausahaan sekolah, administrasi keuangan, gedung dan alat-alat perlengkapan sekolah dan lain-lain.

2. Administrasi personal, mencakup di dalamnya administrasi personal guru dan pegawai sekolah, juga administrasi murid. Dalam hal ini masalah kepemimpinan dan supervisi atau kepengawasan memegang peranan yang sangat penting.

3. Administrasi kurikulum, seperti tugas mengajar guru-guru, penyusunan sylabus atau rencana pengajaran tahunan, persiapan harian dan mingguan dan sebagainya.

\section{Hubungan Pendidikan dan Kebudayaan}

Antara kebudayaan dengan pendidikan terdapat komplementer. Pertama, kebudayaan berperan sebagai masukan (input) bagi pendidikan. Contohnya, tujuan pendidikan ditentukan oleh sistem nilai yang dianut oleh masyarakat (wujud pertama kebudayaan), kurikulum dan metode pendidikan, antara lain akan ditenmtukan oleh nila-nilai, norma-norma, 
dan gagasan-gagasan masyarakat (wujud pertama kebudayaan), serta ditentukan pula wujud kebudayaan sebagai suatu kelakuan berpola dari suatu masyarakat (wujud kedua kebudayaan), adapun wujud ketiga dalam kebudayaan (wujud fisik berupa bangunan, OHP). Akan menjadi alat bantu dalam praktik pendidikan. Kedua, pendidikan berfungsi untuk melestarikan kebudayaan masyarakat (fungsi konservasi) dan juga berfungsi masyarakat ke arah yang lebih baik (fungsi kreasi atau inovasi). (Sulfemi, 2019 : 3.).

\section{Manajemen kurikulum}

Manajemen kurikulum merupakan subtansi manajemen yang utama di sekolah. Prinsip dasar manajemen kurikulum ini adalah berusaha agar proses pembelajaran dapat berjalan dengan baik, dengan tolok ukur pencapaian tujuan oleh siswa dan mendorong guru untuk menyusun dan terus menerus menyempurnakan strategi pembelajarannya. Tahapan manajemen kurikulum di sekolah dilakukan melalui empat tahap : (a) perencanaan; (b) pengorganisasian dan koordinasi; (c) pelaksanaan; dan (d) pengendalian.

\section{Manajemen Kesiswaan}

Dalam manajemen kesiswaan terdapat empat prinsip dasar, yaitu : (a) siswa harus diperlakukan sebagai subyek dan bukan obyek, sehingga harus didorong untuk berperan serta dalam setiap perencanaan dan pengambilan keputusan yang terkait dengan kegiatan mereka; (b) kondisi siswa sangat beragam, ditinjau dari kondisi fisik, kemampuan intelektual, sosial ekonomi, minat dan seterusnya. Oleh karena itu diperlukan wahana kegiatan yang beragam, sehingga setiap siswa memiliki wahana untuk berkembang secara optimal; (c) siswa hanya termotivasi belajar, jika mereka menyenangi apa yang diajarkan; dan (d) pengembangan potensi siswa tidak hanya menyangkut ranah kognitif, tetapi juga ranah afektif, dan psikomotor.

\section{Manajemen keuangan}


Manajemen keuangan di sekolah terutama terutama berkenaan dengan kiat sekolah dalam menggali dana, mengelola dana, pengelolaan keuangan dikaitkan dalam program tahunan sekolah, pengadministrasian dana sekolah dan cara melakukan pengawasaan, pengendalian serta pemeriksaan. Inti dari manajemen keuangan adalah pencapaian efisiensi dan efektivitas.

\section{Manajemen perawatan preventif sarana dan prasana sekolah}

Manajemen perawatan preventif sarana dan prasana sekolah merupakan tindakan yang dilakukan secara periodik dan terencana untuk merawat fasilitas fisik, seperti gedung, mebeler, dan peralatan sekolah lainnya, dengan tujuan untuk meningkatkan kinerja, memperpanjang usia pakai, menurunkan biaya perbaikan dan menetapkan biaya efektif perawatan sarana dan pra sarana sekolah.

\section{E. Fungsi Pendidikan Nonformal}

Fungsi lembaga pendidikan nonformal menurut UU Sisdiknas Tahun 2003 pasal 26 adalah sebagai pengganti, penambah, dan/atau pelengkap pendidikan formal dalam rangka mendukung pendidikan sepanjang hayat. Pada ayat ke 5, kursus dan pelatihan diselenggarakan bagi masyarakat yang memerlukan bekal pengetahuan, keterampilan, kecakapan hidup, sikap untuk mengembangkan diri, mengembangkan profesi, bekerja, usaha mandiri, dan/atau melanjutkan pendidikan ke jenjang yang lebih tinggi. (Sulfemi, $2018: 5$.). 


\section{Kesimpulan}

Hubungan antara fungsi dan bidang garapan manajemen sekolah adalah tentang bagaimana sebuah sistem sekolah dapat berjalan dengan baik, sehingga dalam melaksanakan kegiatan belajar mengajar dapat diterima oleh peserta didik dengan baik. Untung menciptakan hubungan yang baik dengan peserta didik harus melalui bidang garapan manajemen sekolah dan fungsi-fungsi yang ada pada manajemen sekolah. Menyangkut bidang kegitan dan fungsi manajem sekolah ialah sebagai kegiatan atau tindakan-tindakan yang mengacu paa fungsi-fungsi manajemen sekolah untuk mengatur, melaksanakan, mengadministrasian, mengevaluasi dan pangawasan agar peserta didik mengikuti alur kegiatan yang ada disekolah sebagai sebuah nilai cinta terhadap praturan dan lingkungan sekolah. 


\section{A. PILIHAN GANDA}

Berilah tanda (x) pada soal dibawah ini dengan bener!

1. apakah yang dimaksud dengan fungsi manajemen.....
a) Suatu kegiatan
b) Suatu perumusan
c) Suatu ekosistem
d) Suatu pilihan

2. apa yang dimaksud dengan kegiatan dalam fungsi manajemen dibawah ini.....
a) Proses
b) Perkembangan
c) Tindakan-tindakan
d) Perjalanan

3. apakah makna dari kata perencanaan (planning).....
a) Pemilihan dan penetapan
b) Pemikiran
c) Perumusan
d) Permusyawarahan

4. Apa yang dimaksud dengan pengorganisasian (organizing) dalam fungsi manajemen dibawah ini.....
a) Keputusan
b) Perjanjian
c) Perkumpulan
d) Tindakan

5. Fungsi manakah yang paling utama dalam fungsi manajemen dibawah ini.....
a) Perencanaan (planning)
b) Pengorganisasian (organizing)
c) Pelaksanaan (actuating)
d) Pengawasan (controling) 
6. Apakah makna kata dari fungsi manajemen di fungsi pengawasan dibawah ini.....
a) Tindakan
b) Usaha
c) Rencana
d) Kegiatan

7. Manakah fungsi manajemen kurikulum dibawah ini....
a) Mendorong guru untuk menyusun strategi pembelajaran dengan baik
b) Membuat guru lebih disiplin waktu
c) Memberikan peraturan bagi para guru
d) Menciptakan guru yang berkualitas

8. Manakah arti penting dari sebuah perencanaan dibawah ini....

a) Membantu manajemen menyusuaikan diri dengan perubahan-perubahan lingkungan

b) Membantu manajemen agar mudah dalam menghadapi suatu masalah

c) Membuat metode penbelajaran dengan baik

d) Memberikan metode pembelajaran yang mudah dimengerti

9. Dalam manajemen kesiswaan terdapat perinsif dasar, ada berapakah perinsif dasar tersebut....
a) 2
b) 3
c) 4
d) 5

10. Manakah arti dari fungsi pelaksanaan (actuating) dibawah ini....
a) Merencanakan
b) Menekankan
c) Menegaskan
d) Menargetkan 


\section{B. ESSAY}

1. Jelaskan apa yang dimaksud dengan perencanaan ( planning) ?

2. Jelaskan apa yang di kemukakan oleh george R. Terry, (1986) mengenei pelaksanaan ?

3. Sebutkan pengertian pengorganisasian menurut george R. Terry, (1986) ?

4. Jelaskan apa yang dimaksud dengan pengawasan?

5. Sebutkan 4 fungsi esensial manajemen sekolah ? 


\section{Kunci Jawaban}

\section{B. Pilihan Ganda}

1. A

2. $\mathrm{C}$

3. A

4. D

5. C

6. B

7. A

8. A

9. $\mathrm{C}$

10.B

\section{ESSAY}

1. Perencanaan (planning) adalah pemilihan dan penetapan tujan organisasi dan penentuan strategi, kebijaksanaan,proyek, program, metode, sistem anggaran dan standar yang dibutuhkan untuk mencapai tujuan.

2. George R. Terry (1986) mengemukakan bahwa actuating merupakan usaha menggerakkan anggota-anggota kelompok sedemikian rupa hingga mereka berkeinginan dan berusaha untuk mencapai sasaran perusahaan dan sasaran anggota-anggota perusahaan tersebut oleh karena para anggota itu juga ingin mencapai sasaran-sasaran tersebut.

3. "Pengoeganisasian adalah tindakan mengusahakan hubungan kelakuan yang efektif antara orang-orang, sehingga mereka dapat bekerja sama secara efisien dan memperoleh kepuasan pribadi dalam melaksanakan tugas tugas untuk mecapai tujuan tertentu."

4. Pengawasan manajemen adalah suatu usaha sistematik untuk menetapkan standar pelaksanaan dengan tujuan - tujuan perencanaan, merancang sistem informasi umpan balik, membandingkan kegiatan nyata dengan standar yang telah ditetapkan sebelumnya, menentukan dan mengukur 
penyimpangan-penyimpangan, serta mengambil tindakan koreksi yang diperlukan untuk menjamin bahwa sumber daya perusahaan dipergunakan dengan cara paling efektif dan efisien dalam mencapai tujuan perusahaan.

5. 1. penstrukturan waktu

2. Penstrukturan aktivitas yang harus diikuti peserta didik

3. Pendefinisian kecerdasan, kemampuan intelektual, prestasi dan prilaku yang baik 


\section{Daftar Pustaka}

http://akhmadsudrajat.wordpress.com/2008/konsep-manajemensekolah/

https://www.slideshare.net/Indravenskiy/bidang-garapan-manajemenpendidikan

Sulfemi, W. B. (2019). Manajemen Pendidikan Berbasis Multi Budaya.

Sulfemi, Wahyu Bagja. (2019). Manajemen Sekolah.

Sulfemi, Wahyu Bagja. (2018). Modul Manajemen Pendidikan Non Formal. 